\title{
MASCULINE CODE AND READING ACTIVITY ISSUES IN BOYS
}

\section{[MASKULINNI KOD A PROBLEMATIKY CTENARSTVI CHLAPCU]}

\author{
Michal Curin
}

doi: 10.18355/PG.2018.7.1.8

\begin{abstract}
Many testing procedures of reading literacy, research in the measure of interest in reading in children, adolescent and adult populations almost all over the world show a significant difference between genders where boys or men are failing. In this paper, fundamental results of relevant testing procedures and research in this area carried out in the last years are included and illustrate the scale of the issue. In the following section, the results of qualitative research with a focus on reading activities in adolescent boys are presented.
\end{abstract}

\section{Key words}

reading activities, reading literacy, qualitative research

\section{Anotace}

Jak vyplývá z mnohých testování čtenářské gramotnosti, výzkumů obliby čtení jako aktivity u dětské, adolescentní i dospělé populace, v téměř ve všech zemích světa se projevuje významný rozdíl mezi pohlavími a to vždy v neprospěch chlapců či mužů. $\mathrm{V}$ textu příspěvku shrnujeme podstatné výsledky relevantních testování a výzkumů na toto téma z posledních let, které ilustrují rozsah problému. V následující části prezentujeme výsledky svého kvalitativně zaměřeného výzkumu orientovaného především na čtenářství dospívajících chlapců.

\section{Klíčová slova}

čtenářství, čtenářská gramotnost, kvalitativní výzkum

\section{Teoretická východiska}

Budeme-li vycházet z výzkumů čtenářské gramotnosti PISA 2015 (s. 169n.), tak se rozdíl mezi dívkami a chlapci v průměru zemí OECD mírně snižuje, nicméně stále zůstává statisticky významný (činí 27 bodů). Mezi lety 2009 a 2015 se genderový rozdíl mezi zeměmi OECD snížil o 12 bodů, chlapci si polepšili o 5 bodů, dívky si pohoršily o 7 bodů.

Podstatné je ale zjištění, že u chlapců došlo ke zlepšení nejpatrněji ve vyšších úrovních způsobilosti, u dívek k pohoršení u nejnižších úrovní čtenářských dovedností. Vzhledem $\mathrm{k}$ tomu, že největší problémy s uplatněním v běžném pracovním i občanském životě mají chlapci, kteří zůstali pod druhou úrovní způsobilosti, nedošlo v čase k žádnému zásadnímu zlepšení situace, potýkáme se stále stejnými počty těch nejhorších žáků. 
Rovněž také zůstává významná odlišnost mezi jednotlivými státy, co se týká rozdílu mezi chlapci a dívkami. K zemím s nejnižším rozdílem patří Irsko (12 bodů) a Japonsko (13 bodů), k zemím s nejvyšším potom Albánie, Gruzie, Jordánsko (cca 50bodový rozdíl). Je třeba také upozornit na situaci ve Finsku a potažmo ve skandinávských zemích, které se pravidelně umist’ují na vrcholu žebříčku zemí s nejlepším skóre ve čtenářské gramotnosti. Rozdíl mezi chlapci a dívkami činí právě ve Finsku 47 bodů. Tolik obdivovaný úspěch Finska je tedy tažen mladými dívkami, zatímco chlapci výrazně zaostávají.

Ve velké většině zemí je rozdíl mezi nejlépe a nejhưře prospívající dívkami zásadně větší než v případě chlapců. Téměř ve všech zemích se chlapci častěji než dívky nacházejí pod druhou úrovní způsobilosti a stejně tak častěji dívky dosahují nejvyšších úrovní způsobilosti.

V České republice došlo mezi lety 2009 a 2015 ke snížení rozdílu o 22 bodů (stále rozdíl zůstává 26 bodů ve prospěch dívek, což je kolem průměru zemí OECD) (Blazek - Príhodova, 2016).

Odhlédneme-li od čtenářské gramotnosti a soustředíme-li se na vztah obliby aktivity čtení a známek z předmětu český jazyk a literatura, pak vidíme signifikantní rozdíl mezi postojem ke čtení mezi chlapci a dívkami (viz Tabulka 1). Konkrétně u známky z mateřského jazyka a literatury se zde ukazuje velká korelace mezi známkou z tohoto předmětu a oblibou předmětu, obzvláště pak u chlapců (tj. čím horší známka, tím horší postoj ke čtení). Na postoj ke čtení má rovněž významný vliv rodinné zázemí stran vzdělání rodičů a socioekonomický status rodiny.

Tabulka 1. Zdroj: Sekundární analýzy..., 2014, s. 19.

\begin{tabular}{|l|c|c|c|c|}
\multicolumn{4}{c|}{ Charakteristické znaky skupin s odlišnou mírou obliby čtení a matematiky } \\
\hline & 1. & 2. & 3. & 4. \\
\cline { 2 - 5 } & $\begin{array}{c}\text { Maji velmi } \\
\text { rádi čtení }\end{array}$ & $\begin{array}{c}\text { Nemaji } \\
\text { rádi čteni }\end{array}$ & $\begin{array}{c}\text { Maji velmi rádi } \\
\text { matematiku }\end{array}$ & $\begin{array}{c}\text { Nemaji rádi } \\
\text { matematiku }\end{array}$ \\
\hline děvčata & $62 \%$ & $26 \%$ & $48 \%$ & $54 \%$ \\
\hline chlapci & $38 \%$ & $74 \%$ & $52 \%$ & $46 \%$ \\
\hline $\begin{array}{l}\text { alespoň jeden z rodič } \\
\text { vysokoškolák }\end{array}$ & $34 \%$ & $21 \%$ & $26 \%$ & $26 \%$ \\
\hline nízký socioekonomický status & $1 \%$ & $2 \%$ & $1 \%$ & $1 \%$ \\
\hline vysoký socioekonomický status & $29 \%$ & $13 \%$ & $20 \%$ & $19 \%$ \\
\hline jednička z českého jazyka & $54 \%$ & $28 \%$ & $44 \%$ & $43 \%$ \\
\hline jednička z matematiky & $61 \%$ & $45 \%$ & $62 \%$ & $41 \%$ \\
\hline
\end{tabular}

Problematice čtenářství dospělé populace (osob starších 15 let), tj. počtu přečtených knih, vztahu ke knihám, typu četby, velikosti domácí knihovny, analýze mediálního chování ad. se soustavně ve svých výzkumech věnuje Jiří Trávníček (2008, 2011, 2014). Vzhledem k tomu, že to není naším tématem, omezíme se na pouhé konstatování, že situace v dospělé populaci se nijak výrazně $z$ genderového hlediska neodlišuje od populace dětské (tj. vášnivějšími čtenářkami jsou ženy, beletrii preferují rovněž ženy, zatímco muži se orientují na literaturu faktu). 
S využitím stejné metodologie přistoupili ke zkoumání čtenářství ale u středoškolské mládeže Hadkova a Fibiger (2011, s. 28n.). Jejich výzkum byl zaměřen na čtenářství gymnazistů a i zde se přesvědčivě ukazuje genderový rozdíl mezi čtenářstvím chlapců a dívek.

Významným se ukazuje být vliv věku na počet přečtených knih viz tabulka 2 (ještě větší posun bychom nalezli při orientaci pouze na čtenáře, kdy u dívek dochází ke stagnaci až poklesu čtení, u chlapců $\mathrm{s}$ věkem počet knih statisticky významně narůstá). Potvrzuje se tak tendence patrná i u dospělé populace, že tedy s věkem obě pohlaví z hlediska kvantitativního se sbližují (i když se nikdy nevyrovnají), avšak muži už se zjednodušeně řečeno nikdy ke čtení beletrie nedostanou - tato šance byla promeškána. Zaostřeno na nečtenáře je rozdíl opět signifikantní: $58 \%$ chlapců ku $23 \%$ dívek.

Tabulka 2 Zdroj: Hádkova, Fibiger, 2011.

Tab. VII. Prưmèrný počet knih - čtenári i nečtenári

\begin{tabular}{|l|r|r|r|r|}
\hline \multicolumn{1}{|c|}{ kategorie } & $\begin{array}{c}\text { prümĕrný počet ročně } \\
\text { prečtených knih }\end{array}$ & minimum & maximum & $\begin{array}{c}\text { kolik } \\
\text { odpovědělo }\end{array}$ \\
\hline celkem & 9,2 & 0 & 200 & 1031 \\
\hline chlapci & 6,7 & 0 & 80 & 372 \\
\hline dívky & 10,5 & 0 & 200 & 659 \\
\hline mladši & 8,8 & 0 & 200 & 553 \\
\hline starši & 9,6 & 0 & 100 & 477 \\
\hline mladši dívky & 10,5 & 0 & 200 & 339 \\
\hline starši dívky & 10,6 & 0 & 100 & 320 \\
\hline mladši chlapci & 6,1 & 0 & 50 & 214 \\
\hline starši chlapci & 7,6 & 0 & 80 & 157 \\
\hline
\end{tabular}

Pro designování našeho vlastního výzkumu byly nejpodstatnější odpovědi týkající se důvodů, proč žáci nečtou. Nejčastější odpovědí byla: nemáme čas, věnujeme se jiným činnostem ( $84 \%$ chlapců, $42 \%$ dívek); dále: nebaví nás to (67\% chlapců, $37 \%$ dívek); a poslední odpověd', která je příznačná právě pro chlapce: vše, co se chceme dovědět, nalezneme na internetu. Zde se projevila jasná převaha odpovědí chlapců nad odpověd'mi dívek $(61 \%$ chlapců, ale jen $10 \%$ dívek). Ukazuje se zde tendence patrná i v dospělé populaci, totiž že ke krásné literatuře přistupují chlapci a muži jako ke zdroji poznání, k informační studnici, a tak zcela opomíjejí její estetický rozměr. Nelze ovšem předpokládat, že za tímto stavem mohou stát vrozené důvody, je spíše nutné svou pozornost obrátit $\mathrm{k}$ vlivům sociokulturním.

A ještě drobná poznámka ke vztahu klasifikace a čtení. Bylo potvrzeno, že přímá úměra neexistuje. Sice největší počet knih přečtených za rok uvádějí jedničkáři, druhý nejvyšší mají ale čtyřkaři, a u chlapců dokonce čtyřkaři předběhli jedničkáře. Potvrzuje se, že školní hodnocení má jen malou (pokud jakou) vypovídací hodnotu o čtenářství i čtenářské gramotnosti u žáků. Naopak z toho vyplývá, že předmět literární výchova je neoblíbený výrazně u žáků, kteři nečtou nebo čtou velmi málo. (Avšak jak prríhodně podotýká Smetackova (2013) stran školního hodnocení, v zásadě se jedná o neexistující či mnohdy nadhodnocovanou korelaci mezi obsahem hodnocení školního výkonu a obsahem většiny nadnárodních testů. Dále se nevhodně redukuje Slavonic Pedagogical Studies Journal, ISSN 1339-8660, eISSN 1339-9055, Volume 7 Issue 1, February 2018 


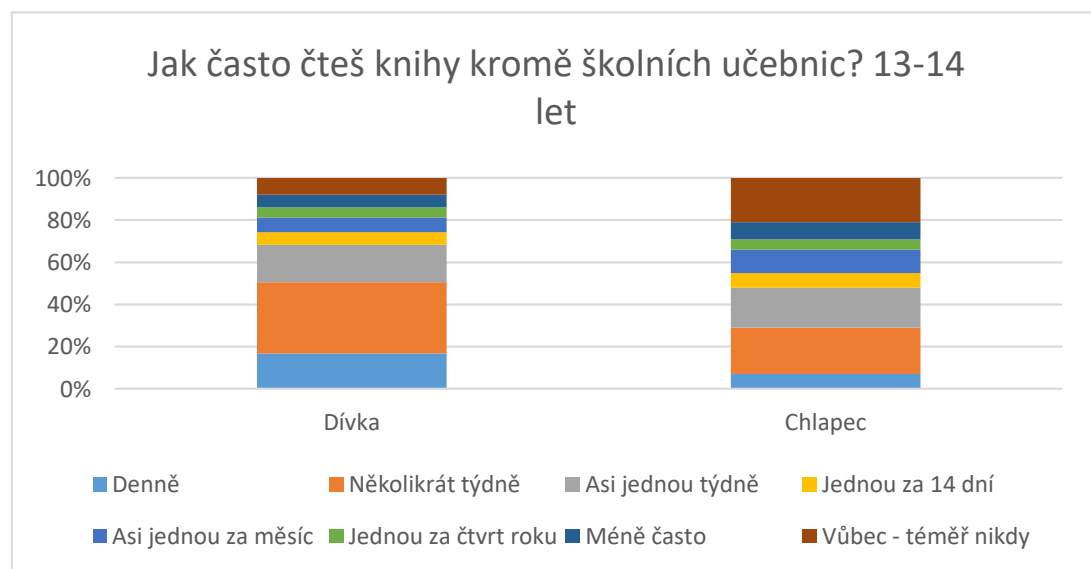

úspěšnost pouze na školní výsledky bez ohledu na př́ípadnou úspěšnost $\mathrm{v}$ následném životě atp.)

\section{Graf 1 Zdroj: Prazova a kol., 2014}

Ze stejného kadlubu jako předchozí uvedený je i výzkum Prázové a kol. (2014) zaměřený na čtenářství dětí. Opět se budeme orientovat pouze aspekty dotýkající se našeho tématu. Přiložený graf (Graf 1) dokladuje, že s věkem se zvětšuje počet nečtenářů u chlapců (u nejmladší skupiny 9-10 let je to pouze $8 \%$ ), a stejně jako $\mathrm{v}$ případě čtenářské gramotnosti je signifikantní právě u chlapců to, že patří $\mathrm{k}$ nejméně častým čtenářum a každodenní čtenáři jsou výrazně méně početní než u dívek.

Nejčastější odpovědí na to otázku, proč chlapci nečtou, je ta, že je to nebaví, což tvrdí asi čtvrtina všech chlapců. Setkáváme se také s poklesem frekvence četby ve srovnání s rokem 2013, kdy denně četlo 33\% dívek a 22\% chlapců, o deset let později to již bylo pouze $15 \%$ dívek a $10 \%$ chlapců. Mediální aktivita se výrazně přesouvá k internetu, zejména $\mathrm{v}$ oblasti mobilních zařízení. A právě vztah chlapců $\mathrm{k}$ moderním technologiím, obzvláště počítačovým hrám je bodem, u kterého je dobré se pozastavit. Podle dotazníkového šetření v rámci testování PISA 2012 (OECD, 2015, s. 43n.) vychází, že chlapci hrají výrazně častěji počítačové hry než dívky. Nabízí se otázka, zda má vliv hraní her na jejich úspěšnost a zda se nějak projevuje odlišnost $v$ herních žánrových preferencích. Jisté korelace se v tomto případě našly. Žáci, kteří se pohybují v četnosti hraní singleplayerových her v hranicích mezi jednou za měsíc a téměř každý den, vykazují ve všech oblastech lepší výsledky než žáci, kteří nehrají počítačové hry vůbec nebo jen zrrídka. Zajímavé ovšem je to, že žáci, kteří hrají multiplayerové (kolaborativní) hry, vykazují horší výsledky. A chlapci obecně upřednostňují právě multiplayerové hry.

Dalším pozoruhodným aspektem doprovázejícím genderový rozdíl je radost ze čtení. Podle PISA 2009 (viz Graf 2) v zemích OECD 40\% žáků uvedlo, že nečtou pro radost. Obzvláště významné je to opět u chlapců, kteří se v případě České republiky ocitli hluboko pod průměrem zemí OECD jako celku, tak i průměru pro chlapce. Alarmující je i trend poklesu zájmu o četbu, mezi lety 2000 a 2009 se v tomto ukazateli ČR výrazně propadla. 
Ukazuje se (OECD, 2015, s. 45n.), že čtení je prospěšné zejména pro žáky s nejnižším skóre. Není velký rozdíl mezi žáky, kteří čtou denně pro radost asi 30 minut a mezi žáky, kteří čtou více než hodinu a půl, ale je podstatný rozdíl mezi žáky, kteří nečtou vůbec a mezi žáky, kteří čtou méně než 30 minut denně pro radost. Samozřejmě, že záleží na tom, co se čte, ale obecně vzato jakékoli čtení pro radost je lepší než žádné čtení. Nejvyšších skórů dosahují téměř ve všech zemích čtenáři beletrie, což, jak již bylo vícekrát uvedeno, chlapci zpravidla nejsou.

Analýza výsledků PISA (tamtéž, s. 48) dokládá, že pokud by chlapci četli pro radost stejně často jako dívky, pak by jejich výsledek ve čtenářských dovednostech byl velmi podobný dívkám. Lze tedy $\mathrm{z}$ toho vyvodit, že nečtenářství beletrie je jedním z největších problémů ohledně rozdílu mezi pohlavími. 
Percentage of students

who read for enjoy ment

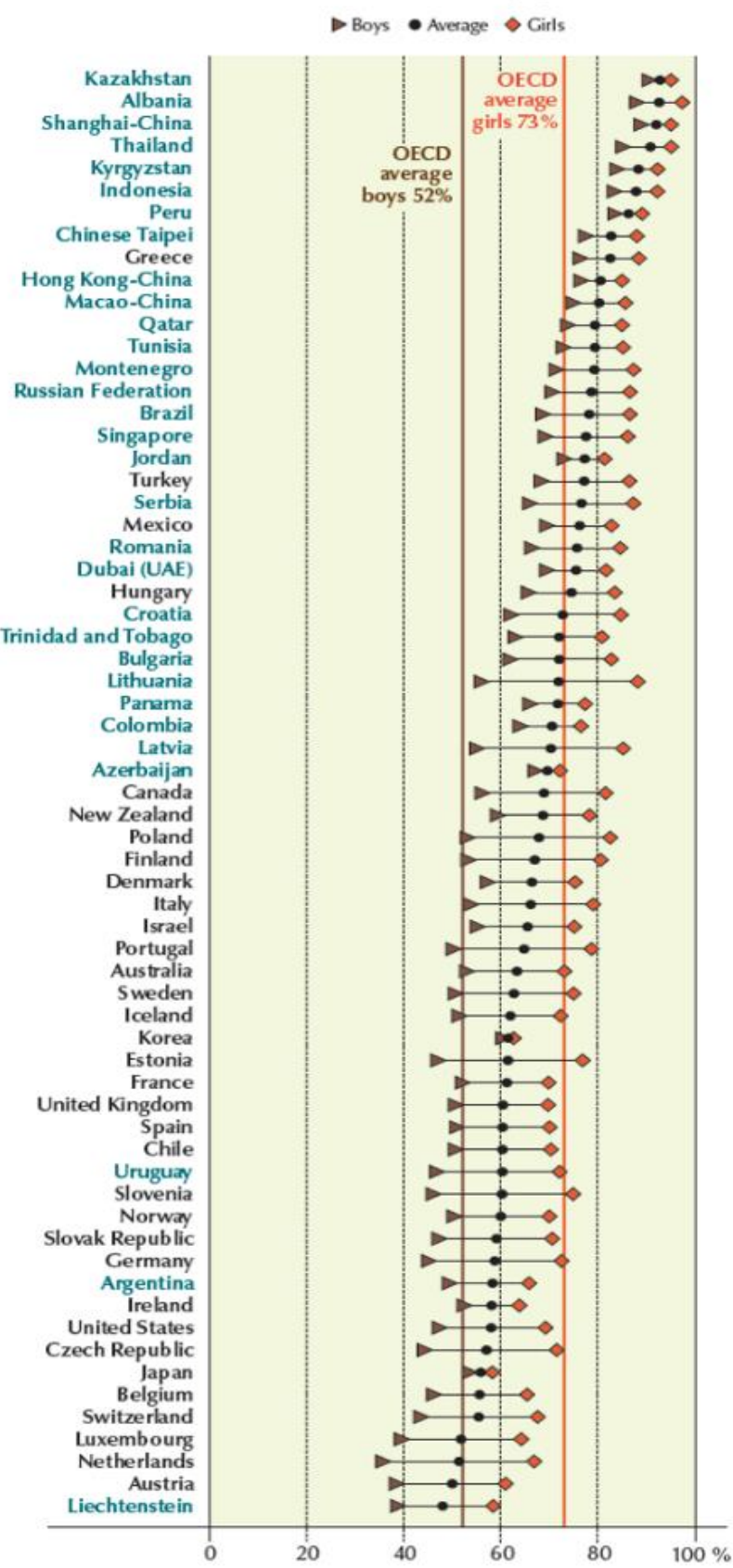

Countries are ranked in descending order of the percentage of students who read for enjoyment.

Source: OECD, PISA 2009 Database, Table III.1.4.

Graf 2 Zdroj: OECD, 2009. 
V souvislosti s volbou druhů literatury (ne/umělecké) je na místě zmínit výzkum Djikicové (Djikic et al., 2013), který se věnoval kognitivnímu uzavření v závislosti na volbě typu textu. Výzkumu byli podrobeni účastníci volící si mezi četbou eseje, či povídky. Následně byli jedinci vystaveni baterii dotazů směrujících ke zjištění jednoznačnosti či mnohoznačnosti postojů. Výsledkem bylo zjištění, že čtenáři beletrie jsou méně náchylní $\mathrm{k}$ jednoznačným postojům, nahlížejí problematiku $\mathrm{z}$ více úhlů pohledu, dokáží se vymezovat $\mathrm{k}$ autorské řeči atd. Jsou to víceméně dovednosti sledované i výzkumy čtenářství PISA a PIRLS. Bez problémů bychom jistě dokázali závěry tohoto výzkumu odvodit intuitivně. Obecně se tuší, že četba beletrie není pouze neproduktivní kratochvílí, ba naopak přispívá $\mathrm{k}$ lepšímu fungování v mnohovrstevnaté a stále se proměňující společnosti.

Výsledky výše uvedených výzkumů byly jedním z popudů k uskutečnění vlastního výzkumného šetření. Ačkoli jsou povětšinou kvantitativní šetření zdrojem cenných dat, cítili jsme potřebu přesunout jádro pozornosti k žákům, vysledovat jejich smýšlení o jevech spojených se čtením a zároveň jim dát svobodu vyjádření, která tak mnohdy chybí ve standardizovaných testech a dotaznících. Dalším ohledem při projektování vlastního šetření byla snaha získat dlouhodobý pohled na jednání a smýšlení, což nám umožnilo sledovat proměny postojů v souvislosti s dospíváním u našich respondentů.

\section{Metodologie}

Šetření bylo prováděno na menší střední škole (200-300 žáků) gymnaziálního charakteru v oblasti s potenciálním větším počtem žáků pocházejících z méně podnětného sociokulturního zázemí. (Průměrná vyšší nezaměstnanost oproti zbytku republiky, menší možnost kulturního vyžití, nižší počet vysokoškolsky vzdělaných mezi rodiči. Daná škola je jedinou stř̌ední školou v místě. Nejbližší větší sídla jsou vzdálena v rozmezí 15 a $30 \mathrm{~km}$. Samotné město disponuje místní knihovnou stř̌ední velikosti, $v$ místě je $\mathrm{k}$ dispozici dům dětí a mládeže a kino a muzeum opět s místní působností.)

. Většina žáků se rekrutuje z menších sídel západní cásti Libereckého kraje. Pro výzkum byli zvoleni výlučně chlapci z jedné třídy, přičemž byl výzkum projektován na celou dobu jejich středoškolské docházky. Na počátku výzkumu v roce 2012 byl počet respondentů 12, na konci výzkumu se jejich počet snížil na 10. Při šetření jsme využili kombinaci různých metod. Jednalo se jednak o opakovaná semistrukturovaná interview s žáky i vyučujícími a ředitelkou školy, focus groups, přímá pozorování výuky, především hodin literární výchovy a dokumentovou analýzu školních kurikulárních dokumentů i textů žáků.

$\mathrm{Z}$ tematického hlediska jsme se orientovali na problematické okruhy, které již dříve definovaly kvantitativní výzkumy. Uprostřed našeho zájmu tak stály oblasti jako jsou: hodnota čtení vnímaná samotnými žáky, postoje rodinných př́islušníků ke čtení a rodinná čtenářská praxe, vnímání literatury, spisovatelů a dalších prvků literárního provozu $\mathrm{z}$ hlediska prestiže ve společnosti a především hodnocení literatury ve vrstevnických skupinách a role školy samožrejmě. 
Na tomto místě budeme prezentovat především výsledky, které se týkají samotného postoje ke čtení s ohledem na genderová specifika, na další výsledky odkazujeme čtenáře do našich dalších publikací, kde jsme prezentovali předchozí fáze výzkumu. (Dílčí závěry testování jsme již dřive uveřejnili, viz Bubenickova 2012 a Curin 2013).

\section{Závěry}

Všichni naši respondenti jsou podle vlastního sebehodnocení čtenáři, toto jejich pojetí koresponduje i s daty, která jsme získali od rodičů a učitelů. Avšak ne všichni respondenti jsou čtenáři beletrie. Přestože na jedné straně školní prostředí vyžaduje a traktuje četbu beletrie a přestože je tato povinnost petrifikována $\mathrm{v}$ rámci současné podoby společné části maturitní zkoušky z literatury, je aktivní četba beletrie u části chlapců pouze fasádou, kterou staví před své spolužáky, rodiče a zejména učitele literatury. Čtení beletrie je u středoškoláka předpokládanou aktivitou, ale ve skutečnosti se prokázalo, že všichni zapojení aktéři (tj. žáci, rodiče, učitelé) tuší či vědí, že se jedná o Potěmkinovu vesnici. Je to jakýsi podivný společně sdílený klam, který jeho členům přináší zdání a reprodukci normálnosti, ve skutečnosti ale jeho udržování nevede $\mathrm{k}$ žádnému posunu na úrovni jednotlivce i společnosti.

Žáci si osvojili zvyk opakovat před autoritami (učiteli a v počáteční fázi šetření i před výzkumníky) naučené formule o prospěšnosti čtení, jeho nezastupitelné roli při vzdělávání i osobnostním vývoji jedince atp. Do úzkých se respondenti dostávali $\mathrm{v}$ okamžiku, kdy měli $\mathrm{v}$ různých fázích výzkumu přikročit $\mathrm{k}$ formulování prospěšnosti čtení pro ně samotné.

Výrazný rozdíl v této oblasti jsme pozorovali u chlapců, v jejichž rodině jsou rodiči aktivními čtenáři beletrie a o četbu jich samotných se zajímají. Takoví respondenti vztahovali četbu k emocionálním prožitkủm, dokázali se vymezit vůči konkrétní literární postavě nebo se $\mathrm{s}$ ní ztotožnit, vyjadřovali se $\mathrm{k}$ motivům jednání literárních postav, dokázali porovnávat různá pojetí téhož tématu $\mathrm{v}$ odlišných textech.

Abychom se dopátrali skutečných postojů žáků, bylo prospěšné nabídnout jim několik fiktivních představ, mikropř́běhů, jejichž aktéry mohli $\mathrm{i}$ nemuseli být, což jim umožnilo poodstoupit od své žité skutečnosti a promýšlet některé jevy z jiného úhlu pohledu.

Přiměli jsme respondenty, aby se zamysleli nad osobou člověka, který miluje knihy (tj. krásnou literaturu), je jejich pravidelným konzumentem, aby takového jedince popsali stran pohlaví, sociálního statusu, povolání, vlastností atd. $\mathrm{Z}$ hlediska pohlaví se respondenti nejčastěji přikláněli $\mathrm{k}$ tomu, že takový jedinec bude pravděpodobně žena, bude spíše introvertem, nestojícím v centru pozornosti, člověkem nepř́iliš úspěšným (rozumějme takovým, který nebude vydělávat vysoké finanční částky), na druhou stranu však bude člověkem společností váženým. Představa čtenáře jako člověka vyčleněného nebo vyčleňujícího se ze společnosti byla velmi zakořeněna $u$ všech respondentů, proto jsme se snažili přijít na to, proč tuto charakteristiku chlapci čtenářům přisuzují.

Nejčastějším důvodem byla pozice čtenářủ jako jedinců, kteří se věnují pouze učení, není s nimi zábava, slangově jsou to „šprti“, jsou oblíbenci 
učitelů, nehrají počítačové hry, nevěnují se sportu či jiné zábavě, kterou preferuje daný jedinec, a proto se s nimi nikdo nechce bavit.

Ukázalo se, že problém pro chlapce při prrípadné definici sebe jako čtenáře nepředstavuje ani tak samotná aktivita čtení, jak image, která je s tímto označením spojována a v konečném důsledku jejich postavení ve vrstevnické skupině. Tuto myšlenku jsme se v rozhovorech a při focus groups pokoušeli ověřit prostřednictvím naznačené modelové situace, kterou měli chlapci doplnit. Měli předvídat reakce svých vrstevníků, kterých by se dočkali $\mathrm{v}$ př́padě, že by místo předem domluvené společné aktivity oznámili, že se budou věnovat čtení zajímavé knihy.

Ukázalo se, že takovou situaci vnímají chlapci ve všech př́ípadech jako problematickou. Projevil se výrazný rozpor mezi jejich deklaratorními prohlášeními ohledně prospěšnosti čtení $\mathrm{s}$ jejich případným reálným jednáním. Z předpokládaných reakcí převažují sociální sankce v podobě odmítnutí, výsměchu, bagatelizace, ostrakizace. I takováto nevinná situace může mít podle chlapců vliv na jejich postavení ve skupině, jehož si velmi cení. Nejčastějším řešením takové nepř́ijemné situace je vůbec ji nevyvolat. Respondenti by se uchýlili ke lži ohledně svých skutečných aktivit, zatajení pravdy, případně zlehčení skutečného důvodu nebo volby nějaké výmluvy.

Níže uvádíme několik autentických vyjádření respondentů:

„, Tak asi by se zasmáli a zeptali, co blbně̌. (...)

„Pravděpodobně by mě měli v uvozovkách za idiota, brali by to částečně jako zradu. "

„Já bych řekl, že by řekli: Ježíš, on si bude čist, to ses zbláznil ne? Tímhle stylem by reagovali. I když my bysme neřekli, že si jdeme čist, my bysme řekli,

že mě bolí noha. "

Když jsme žáky na konci našeho šetření, tj. v jejich 19 letech, konfrontovali s jejich názory coby 15letých, vzbudily tyto ve velké většině pobavení a odmítnutí. S věkem prrirozeně stoupla nezávislost na vrstevnické skupině, chlapci by se již nezdráhali vyslovit svůj názor před skupinou, avšak jejich postoj ke čtení jako takovému zůstal nezměněn. Je-li tedy co zlepšovat v oblasti čtenářství chlapců, musí se brát ohled na vnímání čtení jako genderově vymezeného jevu.

Nejenom na základě těchto výseků výzkumu se domníváme, že zásadní překážkou ve zvýšení počtu čtenářủ mezi chlapci je tzv. maskulinní kód, tedy označení pro soubor nepsaných přesto ale silně a jednoznačně vnímaných norem, které definují a regulují chování muže/chlapce, pokud chce být za správného muže/chlapce považován. Součástí maskulinního kódu je stálá stigmatizace některých aktivit femininními prrívlastky, tedy takových, které se neslučují s mužskou identitou. Maskulinní kód je neodlučitelnou součástí sociálního života v naší kultuře, bylo by tedy chybou hledat za problematickými výkony chlapců v testování i v jejich odlišném nastavení kupř. ke čtení pouze školu, to by totiž mohlo vést ke špatným nástrojům $\mathrm{k}$ nápravě. 


\section{Bibliographic references}

BLAZEK, R. - PRIHODOVA, S. 2016. Mezinarodni setreni PISA 2015: narodni zprava: prirodovedna gramotnost. Praha: Ceska skolni inspekce. $57 \mathrm{~s}$. ISBN 978-80-88087-08-3.

CURIN, M. a kol. 2013. Ctenarstvi v souvislostech. Usti nad Orlici: Oftis. ISBN 978-80-7405-327-6.

DJIKIC, M. - OATLEY, K. - MOLDOVEANU, M. C. 2013. Opening the Closed Mind: The Effect of Exposure to Literature on the Need for Closure. Creativity Research Journal, vol. 25, no. 2, pp. 149-154.

FIBIGER, M. - HADKOVA, M. 2011. Nove ukoly didaktiky materskeho jazyka a literatury (se zamerenim na gymnazia). Usti nad Labem: Univerzita J. E. Purkyne v Usti nad Labem, Pedagogicka fakulta. ISBN 978-80-7414345-8.

OECD. 2009. PISA 2009. Database . [cit. 2017-10-30] Available online: http://pisa2009.acer.edu.au/

OECD. 2015. PISA 2015 Results Volume I. [cit. 2017-10-30] Available online: http://dx.doi.org/10.1787/9789264266490-en

OECD. 2015. The ABC of Gender Equality in Education: Aptitude, Behaviour, Confidence. PISA, OECD Publishing. [cit. 2017-10-30] Available online: http://dx.doi.org/10.1787/9789264229945-en

PRAZOVA, I. et al. 2014. Ceske deti jako ctenari. Prvni vydani. Brno: Host. ISBN 978-80-7491-492-8.

Sekundarni analyzy vysledku setreni PIRLS 2011 a TIMSS 2011. 2014.

Praha: Ceska skolni inspekce. [cit. 2017-10-30] Available online: http://www.csicr.cz/Prave-menu/Mezinarodni-setreni/PISA/Sekundarnianalyzy/Sekundarni-analyzy-vysledku-mezinarodnich-setreni

SMETACKOVA, I. 2013. Genderova rovnost ve vysledcich: znevyhodnuji ceske skoly chlapce, nebo divky? E-pedagogium, roc. 12, c. 1, s. 15-29. [cit. 2017-10-30] Available online: http://old.pdf.upol.cz/fileadmin/user_upload/PdF/e-pedagogium/2013/epedagogium_01_2013.pdf

TRAVNICEK, J. 2008. Cteme?: obyvatele Ceske republiky a jejich vztah ke knize: (2007). Brno: Host. ISBN 978-80-7294-270-1.

TRAVNICEK, J. 2011. Ctenari a internauti: obyvatele Ceske republiky a jejich vztah ke cteni (2010). Brno: Host ve spolupraci s Narodni knihovnou Ceske republiky. ISBN 978-80-7294-515-3.

TRAVNICEK, J. 2014. Preknizkovano: co cteme a kupujeme (2013). Brno: Host. ISBN 978-80-7491-256-6.

ZACHOVA, A. a kol. 2012. Rozmery ctenarstvi. Hradec Kralove: Gaudeamus, 2012. ISBN 978-80-7435-233-1.

Mgr. Michal Čurín

Department of Czech Language and Literature

Faculty of Education, University in Hradec Králové,

Náměstí Svobody 301, Hradec Králové

Czech Republic

michal.curin@uhk.cz 